S2 IImu Kesehatan Masyarakat UGM

\title{
Sistem Kewaspadaan Dini dan Respon di Kabupaten Blora Provinsi Jawa Tengah Tahun 2017
}

\section{LATAR BELAKANG}

Sistem Kewaspadaan Dini dan Respon (SKDR) merupakan upaya pemantauan secara terus menerus penyakit potensial Kejadian Luar Biasa (KLB) yang membutuhkan respon cepat. SKDR mengamati 23 penyakit berpotensi KLB melalui portal online yang sewaktu-waktu dapat memberikan sinyal KLB jika melebihi nilai ambang batas pada masing-masing penyakit.

\section{TUJUAN}

Penelitian ini bertujuan mendeskripsikan laporan SKDR dan penilaian pada proses pelaksanaannya.

\section{METODE}

Data yang dianalisis adalah laporan mingguan SKDR dari 26 Puskesmas di Kabupaten Blora. Analisis dilakukan secara deskriptif. Penilaian SKDR berdasarkan hasil diskusi dengan petugas surveilans Puskesmas dan Dinas Kesehatan Blora.
HASIL

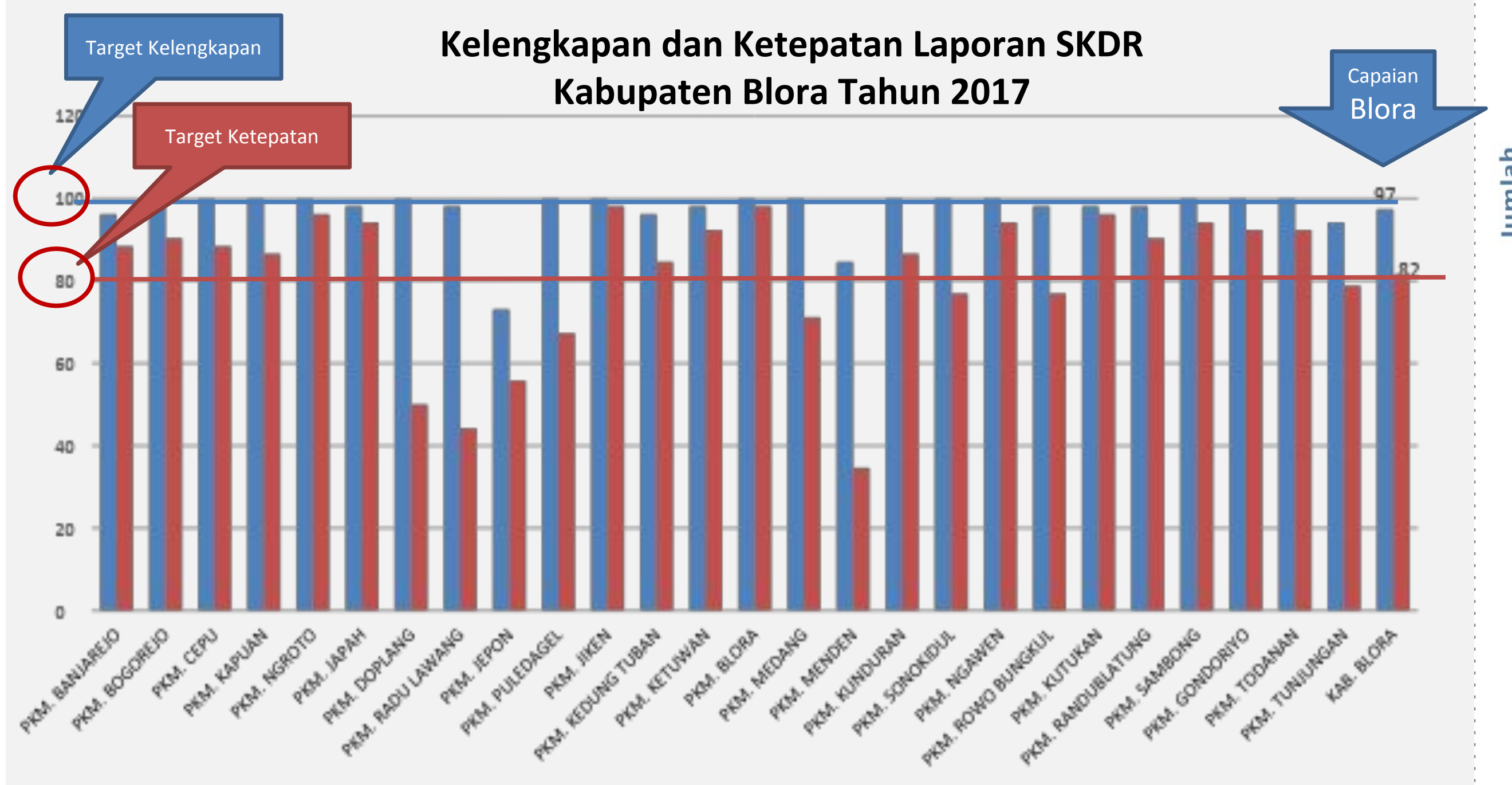

WKelengkapan WKetseptan

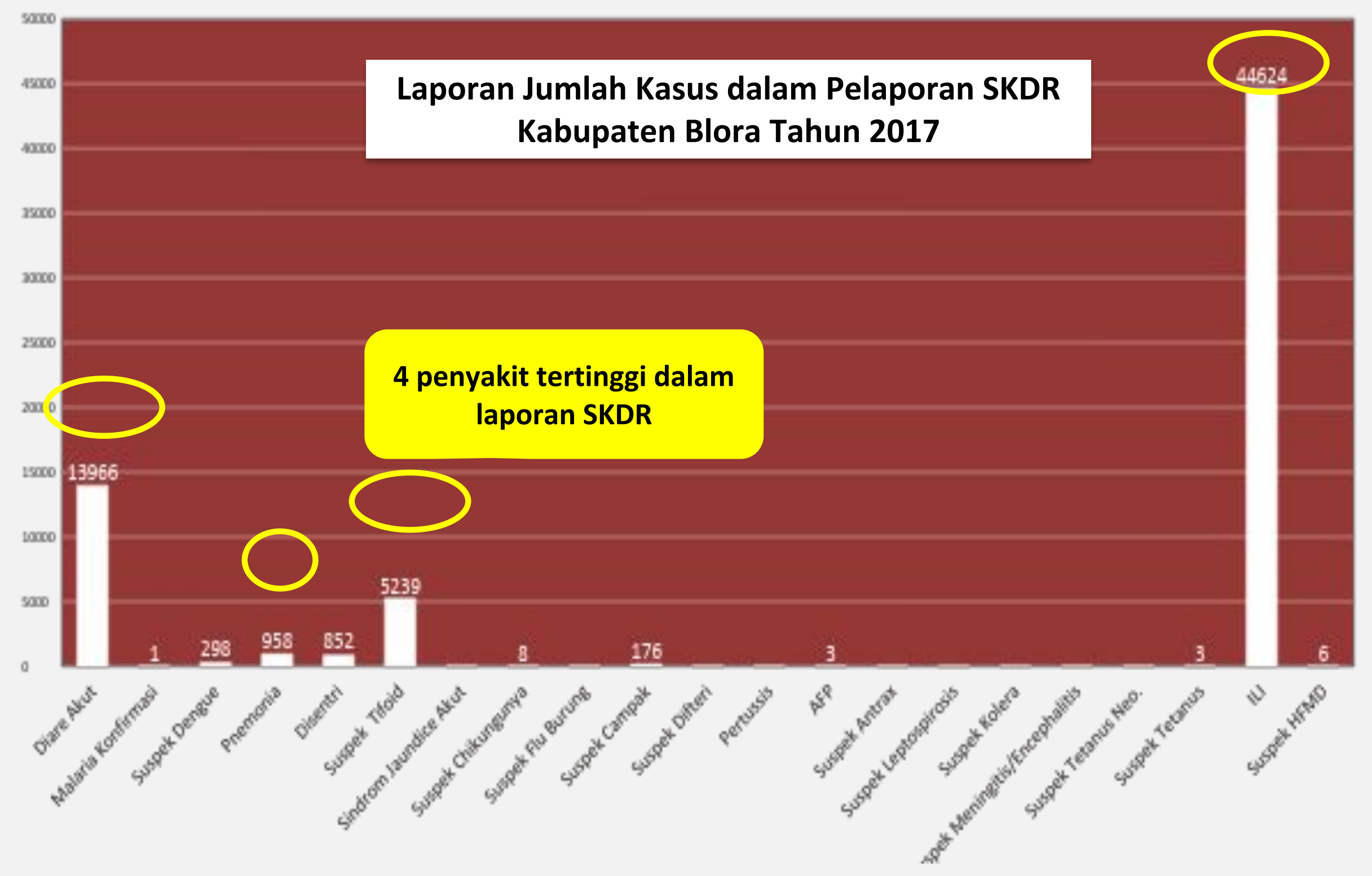

Analisa Alert (Peringatan Dini) di KAB. BLORA / JAWA TENGAH Minggu ke 1 - 52 tahun 2017

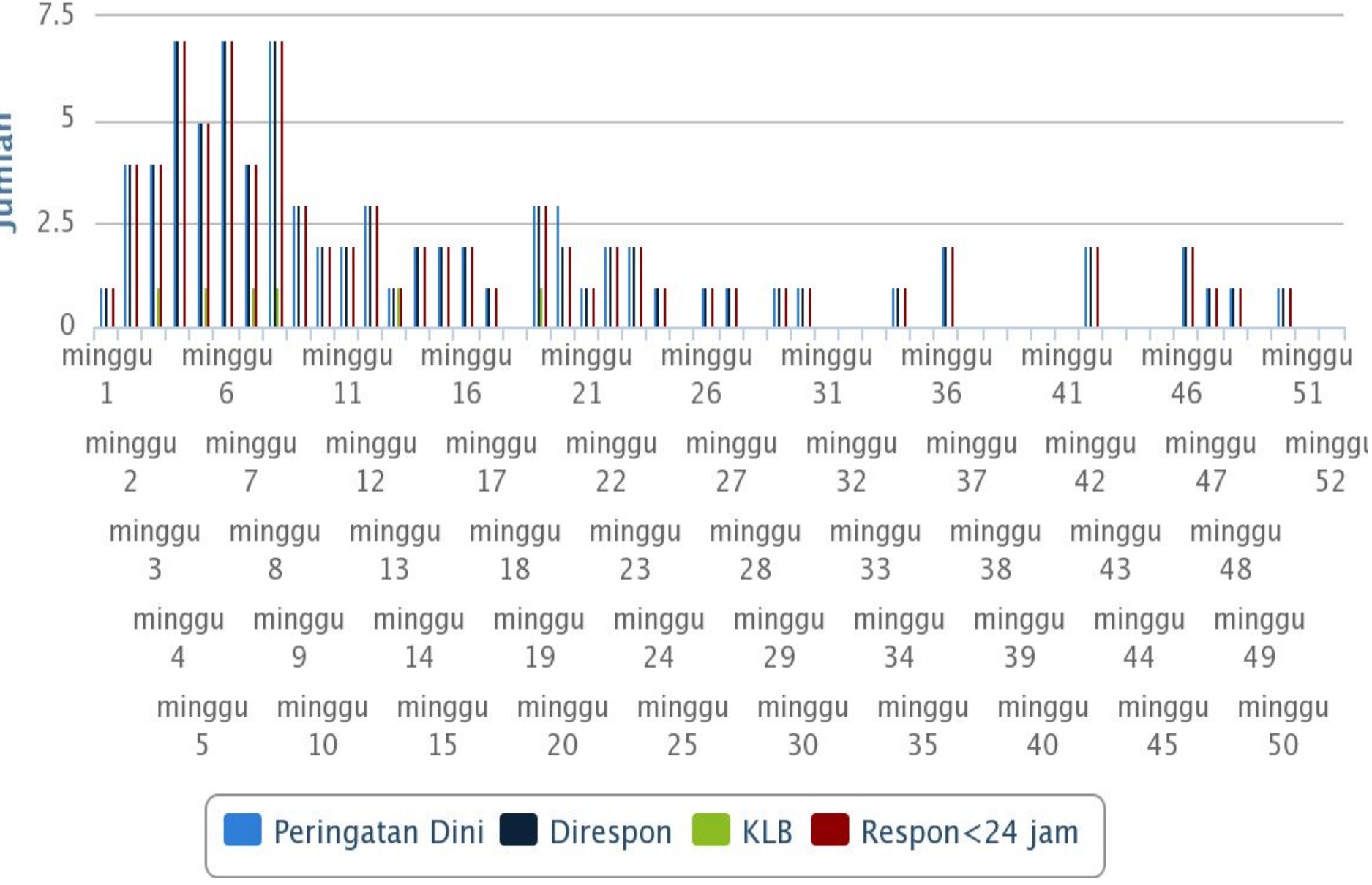

\section{Hasil Indentifikasi Permasalahan SKDR}

- Trend penyakit tidak diolah dan dianalisis pada tingkat Puskesmas.

- Perbedaan sumber laporan setiap puskesmas yang memberikan laporan mingguan SKDR.

- Jumlah layanan kesehatan desa atau Pustu yang mengumpulkan laporan tidak selalu sama setiap minggunya.

\section{KESIMPULAN}

SKDR Kabupaten Blora cukup baik dalam kelengkapan dan ketepatan laporan. Puskesmas dan Dinas Kesehatan perlu memaksimalkan monitoring pada layanan kesehatan yang mengumpulkan laporan.

\section{3rd 앙 Public Health

